\title{
Inhibition in Kainate-Lesioned Hyperexcitable Hippocampi: Physiologic, Autoradiographic, and Immunocytochemical Observations
}

\author{
J. E. Franck, ${ }^{1}$ D. D. Kunkel, ${ }^{1}$ D. G. Baskin, ${ }^{2,4}$ and P. A. Schwartzkroin ${ }^{1,3}$ \\ 'Department of Neurological Surgery, ${ }^{2}$ Biological Structure and Medicine, 3Physiology and Biophysics, University of \\ Washington, Seattle, Washington 98195, and ${ }^{4}$ Veterans Medical Center, Seattle, Washington 98108
}

Following kainate lesions of hippocampal subfield CA3, the remaining CA1 pyramidal cells become hyperexcitable. This lesion is of interest because, morphologically, it resembles the damage often seen in cases of temporal lobe epilepsy; it may provide insight into the consequences of such cell loss in humans. The hyperexcitability in CA1 is associated with a loss of both early and late IPSPs. At long postlesion latencies (2-4 months) inhibition shows partial recovery and the hyperexcitability subsides. The intent of the present work was to determine if alterations in CA1 excitability and functional inhibition postlesion are correlated with changes in morphologic and physiologic indicators of inhibitory interneuron function or with alterations in binding sites for inhibitory transmitters.

Using GAD immunocytochemistry, we found no acute or chronic lesion-induced decrease in numbers of CA1 interneurons or in qualitative characteristics of the pericellular distribution of their terminals in CA1 stratum pyramidale. Intracellular recordings from identified celis in CA1 indicated that putative interneurons were viable in hyperexcitable tissue. It was further observed that "recovery" in tissue studied 2-4 months postlesion primarily involved the early IPSP; the late IPSP failed to reappear. Quantitative in vitro autoradiographic analysis of ${ }^{3} \mathrm{H}$-flunitrazepam-a marker for the early IPSP associated GABA $_{A}$ receptor complex-indicated that hyperexcitability was associated with an increase in $\mathrm{GABA}_{A}$ receptor number in $\mathrm{CA} 1$; receptor binding returned to normal at long postlesion latencies as the early IPSP returned and hyperexcitability subsided. Finally, hyperexcitable pyramidal cells were found to retain their responsivity to exogenously applied GABA.

These data indicate that much of the cellular machinery necessary for inhibition is retained in CA1, despite lesioninduced hyperexcitability. We suggest that the acute loss of the IPSP after kainate lesion is due to a transient discon-

\footnotetext{
Received Apr. 22, 1987; revised Oct. 14, 1987; accepted Oct. 19, 1987.

This work was supported by Program Project NS 20482 and NS 15317 (P.A.S.). Manuscript preparation was supported, in part, by a research grant from the Epilepsy Foundation of America (J.E.F.). Antiserum to GAD was provided through the Laboratory of Clinical Science, NIMH, where it was developed under the supervision of Dr. Irwin J. Kopin with Drs. Wolfgang Oertel, Donald E. Schmechel, and Marcel Tappaz. Effective use in immunocytochemistry was greatly aided through the laboratory of Enrico Mugnaini (University of Connecticut, Storrs, CT).

Correspondence should be addressed to J. E. Franck, Ph.D., at the above address.

Copyright (C) 1988 Society for Neuroscience 0270-6474/88/061991-12\$02.00/0
}

nection between inhibitory and excitatory elements in CA1 and/or to a loss of normal afferent drive from CA3 onto some CA1 interneurons. We further suggest that incomplete recovery can be explained by abnormalities that occur as neuroplastic rearrangements in response to deafferentation of CA1. The relevance of these studies to human hippocampal necrosis and to other models of focal epilepsy is discussed.

Human temporal lobe epilepsy and posttraumatic epilepsy are often associated with a loss of hippocampal subfields (Babb and Brown, 1986). It has been repeatedly hypothesized that selective hippocampal cell loss and resulting plastic changes in remaining neurons may contributc to epileptogenesis. The discoveries that subregions of the hippocampus have receptors for an exogenous toxin, kainic acid (KA) (Foster et al., 1981), that KA causes selective hippocampal cell damage much like that seen in temporal lobe epileptic foci (Nadler et al., 1980a, b), and that KA is one of a family of toxic ligands that are similar to the putative endogenous hippocampal excitatory transmitters (Olney, 1978; Cotman et al., 1981) have raised the possibility that endogenous KA-like substances are responsible for epilepsy-associated damage in hippocampus. Kainate has also provided an experimental means of destroying hippocampal subfields in a clinically relevant pattern so that the function of remaining tissue can be studied.

Spontaneous electrographic and behavioral seizures do occur for some time after KA-induced limbic lesions (Cavalheiro et al., 1982; Tanaka et al., 1985). KA lesions of hippocampal subfields $\mathrm{CA} 3-\mathrm{C} \wedge 4$ induce cellular hyperexcitability and synchrony in CA1 (Franck and Schwartzkroin, 1985; Ashwood et al., 1986) and the dentate gyrus (Tauck and Nadler, 1985). This increased excitability has been shown to be associated both with recurrent excitation (Tauck and Nadler, 1985) and with a transient loss of IPSPs (Franck and Schwartzkroin, 1985). Furthermore, the lost IPSP reappears-i.e., "recovers" (Franck and Schwartzkroin, 1985) - at time intervals that parallel recovery from bchavioral and limbic seizures (Cavalheiro et al., 1982).

The mechanism underlying the transient IPSP loss, and the abnormalities that characterize the hippocampus at different times postlesion, have not been elucidated. In our previous work we found that the CA1 region of hippocampi in which CA 3 had been destroyed by KA had become hyperexcitable when studied in vitro 2-4 weeks postlesion (Franck and Schwartzkroin, 1985). We also demonstrated that, to some extent, "recovery" had occurred by 2-4 months postlesion. The intent of the present work was to examine inhibitory function in the CAl region at 
these same intervals, particularly during increased excitability. In the present series of studies, we examined both pre- and postsynaptic features of inhibitory function in hyperexcitable and "recovered" KA-lesioned hippocampi. An immunocytochemical approach was used to determine if glutamic acid decarboxylase (GAD)-immunoreactive cells (presumably GABAergic) are present in hyperexcitable hippocampi. Quantitative autoradiography was used to examine the distribution and characteristics of binding sites related to the inhibitory neurotransmitter, GABA, in lesioned hippocampi. And, finally, intracellular electrophysiologic methods were used to determine if putative interneurons were viable in the region of pyramidal cell hyperexcitability and if these pyramidal cells retain their ability to respond to GABA.

\section{Materials and Methods}

Animals and surgical procedures. Adult male and female Long-Evans rats, 70-90 d of age at the beginning of the study, were used. Rats were anesthetized with Equithesin $(0.3 \mathrm{ml} / 100 \mathrm{gm}$, i.p.), and KA was bilaterally injected (intraventricularly) over a $10 \mathrm{~min}$ period $(0.5 \mu \mathrm{g}$ in $1 \mu \mathrm{l}$

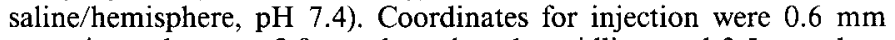
posterior to bregma, $2.0 \mathrm{~mm}$ lateral to the midline, and $3.5 \mathrm{~mm}$ deep to the dura (Pellegrino and Cushman, 1967). A total of 41 animals was divided among the experiments as follows: physiology: control, $n=5$; 2-4 wecks postlesion, $n=7 ; 2-4$ months, $n=5$; immunocytochemistry: $n=3$ for each group; autoradiography: $n=5$ for each group. Both unoperated rats and rats that received only intraventricular saline injections served as controls.

Physiology. The CA1 region of hippocampi from lesioned and control rats was studied at $2-4$ weeks or $2-4$ months postlesion. Transverse slices, $400 \mu \mathrm{m}$ thick, were prepared and maintained as previously described (Franck and Schwartzkroin, 1985). Since the lesion produced with intraventricular KA is restricted to dorsal hippocampus, slices (68/experiment) were taken only from this region. In each slice, the CAl population response was characterized so that subsequent intracellular records could be correlated with the presence or absence of afterdischarge activity. Typically, a $0.1-0.3 \mathrm{~mA}$ pulse $(50 \mu \mathrm{sec}$ duration) was delivered to either the alveus (antidromic activation of pyramidal cells) or stratum radiatum (orthodromic activation) at a rate of $0.3-2 \mathrm{~Hz}$ through bipolar tungsten electrodes. Field potentials were recorded with $2 \mathrm{M} \mathrm{NaCl}$ pipettes (3-5 M 2 ).

Intracellular recordings were made from $\mathrm{CA} 1$ neurons with $4 \mathrm{M}$ potassium acetate electrodes (50-80 M $\Omega$ ). Current injection during recording was carried out using a standard bridge circuit, and bridge balance was monitored throughout each recording session. Neuronal input resistance $\left(R_{\text {in }}\right)$ was estimated by injecting a $100 \mathrm{msec}$ hyperpolarizing constant-current pulse $(0.5 \mathrm{nA})$, and calculating resistance from the steady-state voltage deflection. In some experiments, GABA (1 mM in physiologic saline, $\mathrm{pH}$ 6.4) was applied at the soma layer, in close proximity to the impaled cell, by pressure ejection ( 70 msec pulses, 30 psi) every $30 \mathrm{sec}$. All data was stored on magnetic tape for subsequent off-line analysis.

In selected experiments, pyramidal cells and presumed interneurons were intracellularly labeled with Lucifer yellow $(4 \%$ in $\mathrm{LiCl})$ by passing constant DC hyperpolarizing current $(0.5 \mathrm{nA})$ for $10-15 \mathrm{~min}$. The slices were removed from the chamber $1 \mathrm{hr}$ after filling and were immersionfixed in buffered formalin. The slices were then infiltrated with $30 \%$ sucrose in $0.1 \mathrm{M}$ phosphate buffer and sectioned $(75 \mu \mathrm{m})$ on a freezing microtome. These thinner slices were wet-mounted in buffer, and filled cells were located. Physiologic characterization of the cells was always carried out before cell filling was initiated.

Immunocytochemistry. The animals were anesthetized and perfused with $3 \%$ paraformaldehyde in $0.1 \mathrm{M}$ phosphate buffer ( $\mathrm{pH} 7.4$ ) containing $0.34 \% \mathrm{l}$-lysine and $0.05 \%$ sodium $\mathrm{m}$-periodate (Kunkel et al., 1986). Brains were postfixed for $2-24 \mathrm{hr}$ in the same fixative at $4^{\circ} \mathrm{C}$ and the hippocampus removed. Tissue blocks were infiltrated with $30 \%$ sucrose in buffer and transverse serial sections were cut at $30 \mu \mathrm{m}$ on a freezing microtome.

Sections for immunocytochemistry were processed according to modifications of the indirect peroxidase-antiperoxidase (PAP) method (Sternberger, 1979). Prior to immunocytochemical staining, tissue sec- tions were pretreated in alchohol/hydrogen peroxide as follows: $70 \%$ ethanol, $5 \mathrm{~min} ; 100 \%$ methanol with $1 \%$ peroxide, $10 \mathrm{~min} ; 70 \%$ ethanol, $5 \mathrm{~min}$. After thorough rinsing in phosphate or Tris-buffered saline ( $\mathrm{pH}$ 7.4 ), the sections were incubated as follows: primary GAD anti-serum $\left(1: 100-1: 200 ; 48-72 \mathrm{hr} ; 4^{\circ} \mathrm{C}\right)$; rabbit anti-sheep IgG $\left(1: 30 ; 60 \mathrm{~min} ; 37^{\circ} \mathrm{C}\right)$; sheep PAP $\left(1: 100 ; 60 \mathrm{~min} ; 37^{\circ} \mathrm{C}\right)$. The primary GAD antiserum (Oertel et al., 1981) was diluted in $0.05 \mathrm{M}$ buffer containing $1 \%$ normal rabbit serum and $0.1 \%$ Triton X-100. Rinses in PBS containing $0.1 \%$ Triton occurred between each incubation. Sections were then reacted with $0.04 \%$ $3,3^{\prime}$-diaminobenzidine (Sigma; diluted in $0.1 \mathrm{~m}$ Tris) and $0.003 \%$ hydrogen peroxide (8-15 min), rinsed, mounted, dehydrated, and coverslipped.

Autoradiography. In vitro autoradiographic techniques were used to examine the distribution and characteristics of binding sites for flunitrazepam (FLU), which is known to bind with high affinity to the benzodiazepine (BZ) moiety on the $\mathrm{GABA}_{\mathrm{A}}$ receptor complex (Enna and Karbon, 1986) and thus is an excellent marker for this complex.

Animals were perfused with $0.1 \%$ paraformaldehyde in $0.2 \mathrm{M}$ cacodylate-buffered saline $(\mathrm{pH} \mathrm{7.4)}$. The brains were rapidly immersed in liquid freon and stored at $-60^{\circ} \mathrm{C}$ until sectioning no more than 1 week later. Coronal cryostat sections, $8-10 \mu \mathrm{m}$, were finger thawed onto cold, subbed microscope slides and returned to the freezer in dessicated boxes. The slides were prewashed in $0.17 \mathrm{M}$ Tris $\mathrm{HCl}(\mathrm{pH} \mathrm{7.4)}$ for $30 \mathrm{~min}$ and then incubated in the same buffer containing varying concentrations of tritiated FLU (0.5-12 nM; New England Nuclear; specific activity, 92.3 $\mathrm{Ci} / \mathrm{mmol}$ ) for $40 \mathrm{~min}$. The incubation was terminated by two $1 \mathrm{~min}$ rinses in buffer followed by rapid washing in distilled water. The tissue was dried immediately under a stream of cold air. Parallel slides were incubatcd at cach ligand concentration with excess unlabeled diazepam (650 $\mathrm{nm}$ ) to determine nonspecific binding. All incubation steps were performed on ice.

The slides were apposed to LKB Ultrofilm and exposed for 3 weeks. The films were analyzed densitometrically on an Apple computer-based system (Baskin et al., 1986), and regions of interest within the hippocampus were referenced to tritiated brain mash standards prepared as previously described (Unnerstall et al., 1982). Optical densities over the regions of interest were converted to pmole/mg protein according to the conversion of Unnerstall et al. (1982), and FLU receptor number and affinity were determined by Scatchard analysis. Two hippocampal regions were chosen for analysis: stratum radiatum of CAl and the dentate gyrus molecular layer. The lesion produced in the present study destroys much of the CA3 Schaffer collateral input to CA1 stratum radiatum, and this region is a likely site of potential receptor alterations. The dentate molecular layer was chosen as a control region, although it has been shown that aberrant recurrent mossy fibers grow into this region following more extensive KA-induced hippocampal lesions (Tauck and Nadler, 1985).

Gray and white matter differentially quench tritium (Herkenham and Sokoloff, 1984; Geary et al., 1985). We attempted to quantify this quenching so that subsequent FLU binding could be corrected to accurately reflect receptor parameters. Slide-mounted tissue sections identical to those used for receptor binding were soaked in a conventional subbing solution containing tritiated ornithine (New England Nuclear; $25-50 \mu \mathrm{Ci} / 100 \mathrm{ml}$; specific activity, $20 \mathrm{Ci} / \mathrm{mmol}$ ) for $30 \mathrm{~min}$ at $37^{\circ} \mathrm{C}$. The slides were dried, and one was apposed to Ultrofilm with each set of receptor binding slides. This procedure resulted in a relatively even layer of radioactivity over the tissue sections, and any subsequent differences in optical density were attributed to lesion-induced differential quenching.

\section{Results}

The appearance of the lesion produced by KA has been extensively documented (Nadler et al., 1980a, b; Franck, 1984; BenAri, 1985). Subfield CA3 is destroyed and CA1 and the dentate gyrus remain undamaged.

\section{Pyramidal cell physiology}

\section{Population responses}

The physiologic characteristics of subfield CA1 in slices from lesioned tissue were like those previously described (Franck and Schwartzkroin, 1985). Slices from 7 rats, lesioned $2-4$ weeks previously, were examined. In each experiment, slices respond- 

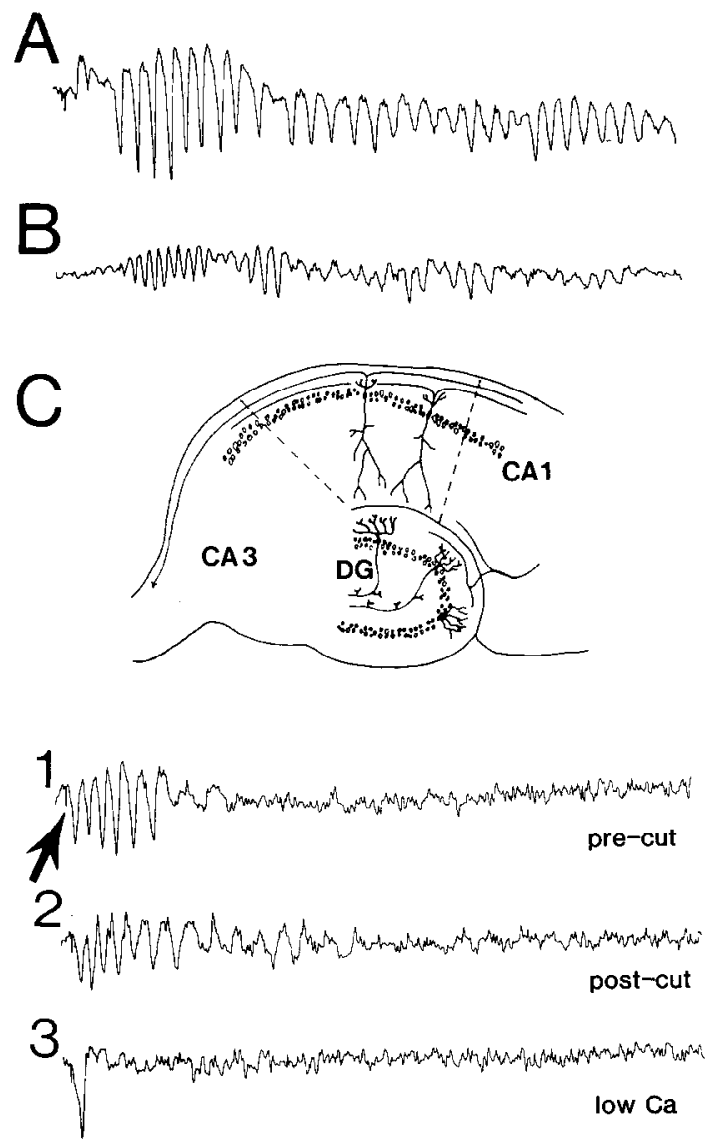

4
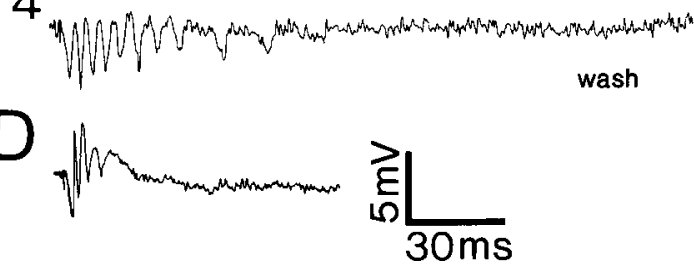

Figure 1. Characteristic neuronal population responses in $\mathrm{CAl}$ at 24 weeks $(A-C)$ and $2-4$ months postlesion $(D)$. Multiple population spikes were produced by orthodromic stimulation in stratum radiatum $(A)$ and occurred spontaneously in some animals $(B)$. In 3 experiments, medial and lateral portions of individual slices were transected to isolate $C A 1$ from the remainder of the tissue ( $C$, hatched lines). Alveus stimulation (arrow) of this isolated CAl produced aberrant population responses both prior to $(C I)$ and following transection $(C 2)$. When the same tissue was perfused with medium containing low calcium, to eliminate synaptic transmission, all but the antidromic population response disappeared $(C 3)$. Reperfusion with normal medium restored the synaptic multispike population response (C4). Similar stimulation parameters in normal medium in CAl from tissue lesioned 2-4 months previously elicited several small population spikes in some experiments $(D)$. However, this response was much less vigorous than population bursts elicited from shorter survival tissue (e.g., that shown in $A$ ). Such bursts never occurred spontaneously in the slices from 2-4 month survival hippocampus.

ed to ortho- or antidromic stimulation $(<0.3 \mathrm{~mA}, 0.3-2 \mathrm{~Hz})$ with markedly abnormal multiple population spikes and repetitive afterdischarge activity like that shown in Figure 1A. Episodes of afterdischarge activity also occured spontaneously (Fig. $1 B)$.

In 3 experiments, a series of cuts was made in hyperexcitable slices with fine forceps, successively isolating the recorded region of CA1 from the remainder of the slice (Fig. $1 C$ ). Removing more medial parts of $\mathrm{CA} 1$, and lateral regions corresponding to
CA2 and the remnants of CA3, had no effect on the occurrence of multiple population spikes elicted by alveus stimulation (cf. Fig. 1, Cl and C2). Following CA1 isolation, the slices were perfused with low $\mathrm{Ca}^{2+} / \mathrm{high} \mathrm{Mg}^{2+}(0.5 \mathrm{~mm} / 8 \mathrm{~mm})$ to block synaptic transmission. CA1 was then stimulated from the alveus. In each instance ( $n=5$ slices), multiple population spikes disappeared, leaving only the antidromic response (Fig. 1C3). When normal medium was reintroduced, repetitive population responses returned (Fig. 1C4). These experiments suggest that hyperexcitability in lesioned slices is synaptically mediated and locally generated.

Slices were also examined from $2-4$ months postlesioned tissue. Five experiments were performed, and in each case the field response elicited by stratum radiatum or alveus stimulation consisted of a single large primary population spike followed by 1-3 smaller spikes (Fig. 1D). Often, the synaptically mediated additional spikes could only be elicited by mild tetanization (5$10 \mathrm{~Hz}$ ). The occurrence of spontaneous afterdischarge activity (i.e., repetitive large-amplitude population spikes) characteristic of $\mathrm{CAl}$ at $2-4$ weeks postlesion was never observed in tissue examined 2-4 months postlesion.

\section{Single-cell responses}

Following field screening, individual pyramidal cells were examined in both hyperexcitable slices from the 2-4 weeks postlesion interval and in slices showing small multiple population responses at 2-4 months postlesion. When possible, characterized neurons were filled with Lucifer yellow, and, in each of the 10 successful fills, the pyramidal nature of the cell was confirmed.

From tissuc at 2-4 weeks postlesion, 15 cells were recorded from slices showing aberrant hyperexcitability in 7 experiments. These cells were compared with 12 pyramidal cells recorded from normal or sham-lesioned tissue in 5 experiments. Each cell had a resting membrane potential of at least $-50 \mathrm{mV}$ and an action potential amplitude of at least $60 \mathrm{mV}$. As was found previously (Franck and Schwartzkroin, 1985), the mean $R_{\text {in }}$ of CA1 pyramidal cells in slices lesioned 2-4 weeks previously was high relative to control values ( $41 \pm 8 \mathrm{M} \Omega$ vs $26 \pm 3 \mathrm{M} \Omega$ ). Synaptic responses in the cells from lesioned tissue were also markedly abnormal. All CA1 pyramidal cells in sham-lesioned or unlesioned hippocampi responded to radiatum stimulation with a brief EPSP (or action potential), followed by an IPSP/ afterhyperpolarization, as exemplified by the response from the pyramidal cell shown in Figure $2 A$ (inset). Most (11/15) CA1 neurons studied in slices from tissue $2-4$ weeks postlesion had no IPSP. These neurons responded to radiatum or alveus stimulation with a prolonged EPSP or a large burst of action potentials, such as in Figure $2 B$ (inset). Repetitive stimulation of such neurons in lesioned slices (Fig. $2 C$ ) also elicted aberrant burst discharges (Fig. 2D).

We attempted to determine whether the orthodromically or antidromically elicited IPSP was more diminished in hyperexcitable cells. Some pyramidal cells studied that had no IPSP in response to one mode of stimulation could respond with a hyperpolarization to the other mode; however, most aberrant neurons $(8 / 11)$ failed to show an IPSP to both radiatum and alveus stimulation.

Of 9 pyramidal cells examined $2-4$ months postlesion, all responded to stimulation with a small EPSP, or single action potential, followed by an IPSP. When repetitive stimulation was presented $(10 \mathrm{~Hz})$, depolarizing afterpotentials developed, but 

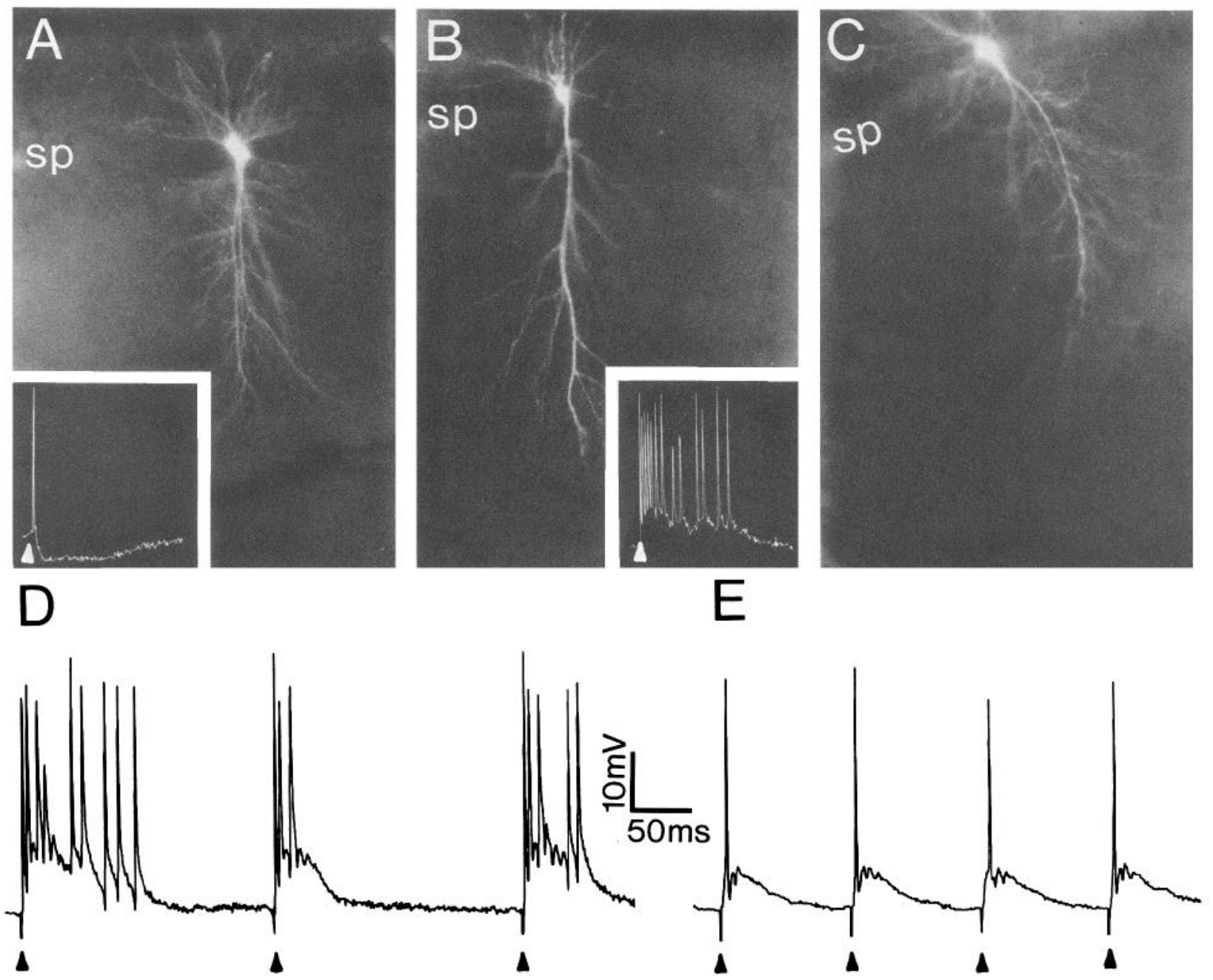

Figure 2. Intracellular responses from normal and lesioned hippocampus. Normal pyramidal cells $(A)$ responded to stimulation (arrowhead in inset) with a single action potential followed by an IPSP/afterhyperpolarization. Hyperexcitable neurons from tissue lesioned $2-4$ weeks previously $(B$ and $C$ ) responsed to similar stimulation with a burst of action potentials riding on a large underlying depolarization (inset in $B$ ). Each stimulus of a $5 \mathrm{~Hz}$ train produced similar bursts in hyperexcitable pyramidal cells $(D)$. However, even when the stimulation rate was increased to $10 \mathrm{~Hz}$, cells from tissue lesioned $2-4$ months previously failed to generate synaptic bursts $(E)$. $s p$, stratum pyramidale.

synaptic bursts did not occur (Fig. 2E). In this respect, cells from this tissue appeared much like those observed in normal hippocampus. In spite of our observations of small, multiple population spikes in this tissue, stimulation did not induce multiple action potentials or burst discharge in single neurons.

We tested cells from tissue lesioned $2-4$ months previously to determine if the IPSP that occurred had the same properties as the IPSP normally observed in control neurons. Subthreshold stimulation in control slices produces a rapid, readily reversible, hyperpolarization followed by a more prolonged late IPSP (Fig. $3 A$ ) that is mechanistically different from the early IPSP and cannot be easily reversed with hyperpolarizing current injection (Fig. 3B; Alger, 1984). The IPSPs elicited in $2-4$ month postlesion tissue tended to be small compared with those observed in control cells (Fig. 3C). Table 1 shows the latency and magnitude of the early, presumably chloride-dependent, IPSP produced by orthodromic stimulation (set just below spike firing threshold). Also shown is the total period of poststimulus hyperpolarization, reflecting a combined duration of early and late IPSPs.
There was no difference between control and lesioned tissue in early IPSP latency or amplitude; however, the total duration of hyperpolarization in pyramidal cells from hippocampi lesioned 2-4 months previously was significantly attenuated relative to control values $\left(t_{15}=2.95 ; p=0.009\right)$.

These data corroborate our earlier work showing that, at relatively brief intervals following KA lesions of $\mathrm{CA} 3$, subfield $\mathrm{CA} 1$ is hyperexcitable in a manner that appears to reflect a loss of the IPSP in the majority of CA1 pyramidal cells. The persistence of CA1 hyperexcitability in slices where CA1 was isolated from the remainder of the tissue, and its dependence on $\mathrm{CA}^{2+}$ concentration, also suggests that recurrent excitation plays a role in aberrant activity.

At longer intervals postlesion, most (if not all) pyramidal cells have IPSPs; this "recovery" is reflected in a population response that, while not entirely normal, is clearly different from the seizure-like activity observed at the earlier postlesion intervals. Even at this later time, however, the IPSP observed in CA1 neurons does not include the late component, suggesting that this tissue fails to recover completely. 


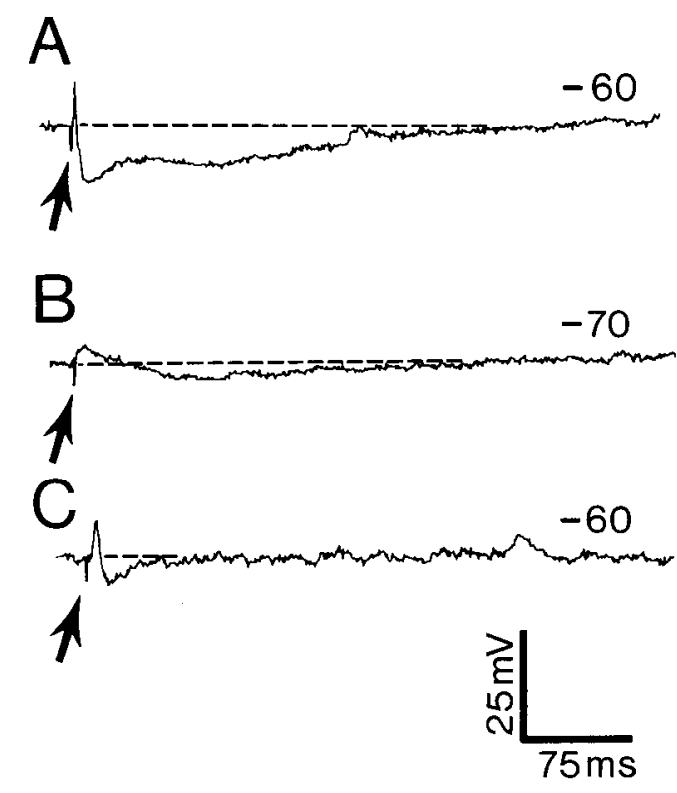

Figure 3. Attenuation of IPSPs in lesioned tissue. Stratum radiatum stimulation (arrow) in normal tissue produced a brief EPSP followed by both an early IPSP and a more prolonged, later hyperpolarizing component $(A)$. Constant hyperpolarizing current injected into normal neurons reverses the early IPSP and reduces, but does not completely reverse, the later hyperpolarizing potential $(B)$. In contrast, in slices from tissue lesioned $2-4$ months previously neurons that did show an IPSP typically responded with only the early component $(C)$.

\section{Presynaptic features of inhibition}

\section{Interneuron morphology}

At a time when physiologic experiments demonstrate marked hyperexcitability, the distribution of GAD immunoreactivity in CA1 appears essentially like that seen in control tissue (Fig. 4, $B$ and $A$, respectively). There is no evidence of degenerating GAD-reactive somata in lesioned tissue, and viable GAD-positive cells are apparent throughout strata oriens and radiatum and within stratum pyramidale (Fig. 4C). The characteristic GAD-positive pericellular terminal plexus also appears unaltered at the light microscopic level $2-4$ weeks postlesion in both CA1 and adjacent CA2 (Fig. 4D). The number of GAD-positive cells in an area of CA1, extending $1 \mathrm{~mm}$ mediolaterally and, in the other dimension, from the base of the pyramidal cell layer to the hippocampal fissure, were counted in 10 sections from each of the 3 controls and 2-4 week postlesion rats. There was no difference in the mean $( \pm \mathrm{SD})$ number of somas present (control, $12.3 \pm 3 /$ section; lesion, $10.9 \pm 2 /$ section).

\section{Interneuron physiology}

Since interneurons did persist in subfield CA1 of lesioned tissue, we attempted to gain some information about their functional characteristics. Schwartzkroin and Mathers (1978) have previously shown that interneurons can be reliably distinguished from pyramidal cells on the basis of spike duration, time constant, afterhyperpolarization amplitude, and adaptation to depolarizing current injection. Ten neurons recorded at $2-4$ weeks postlesion and 5 neurons recorded at 2-4 months postlesion were identified as "nonpyramidal" based on these criteria. The putative interneurons recorded at the early postlesion interval were observed in regions of CA1 in which the population response reflected tissue hyperexcitability. Four of these cells were filled
Table 1. Latency and magnitude (mean \pm SEM) of the early IPSP and the total period of hyperpolarization observed intracellularly following subthreshold orthodromic stimulation in cells from control and 2-4 months postlesioned tissue

\begin{tabular}{llll} 
Group & $\begin{array}{l}\text { Early IPSP } \\
\text { peak latency } \\
(\mathrm{msec})\end{array}$ & $\begin{array}{l}\text { Early IPSP } \\
\text { peak ampli- } \\
\text { tude }(\mathrm{mV})\end{array}$ & $\begin{array}{l}\text { Total hyper- } \\
\text { polarization } \\
(\mathrm{msec})\end{array}$ \\
\hline Control $(n=8)$ & $17.5 \pm 2.4$ & $7.5 \pm 1.4$ & $229 \pm 37$ \\
$2-4$ months $(n=9)$ & $21.3 \pm 3$ & $7.3 \pm 1.4$ & $109 \pm 19^{a}$
\end{tabular}

${ }^{a} t_{15}=2.95 ; p=0.009$, relative to controls.

with Lucifer yellow and in each instance were observed to be aspinous cells with sparse bipolar dendrites extending both into stratum oriens and deep into stratum radiatum (Fig. 5), features characteristic of the interneuron type described by Schwartzkroin and Kunkel (1985). The interneuron shown in Figure 5, $A$ and $B$, appears dye-coupled to a pyramidal cell, a phenomenon we also occasionally observed in control tissue.

The physiologic characteristics of the interneuron shown were typical of those seen in slices at both postlesion intervals. $R_{\text {in }}$ values of interneurons in lesioned tissue were not significantly different from $R_{\text {in }}$ of 3 interneurons recorded from normal tissue (control, $41 \pm 5.2 \mathrm{M} \Omega$; 2-4 weeks, $36 \pm 13.6 \mathrm{M} \Omega ; 2-4$ months, $36.2 \pm 6.5 \mathrm{M} \Omega$ ). The identified interneurons of all groups responded to current injection with a characteristic prolonged train of action potentials (Fig. $5 \mathrm{Cl}$ ). All interneurons studied in control tissue and at 2-4 months postlesion responded to stimulation with an EPSP, or action potential, followed by an IPSP and/or afterhyperpolarization (Fig. 5C2). A number of interneurons examined 2-4 weeks postlesion failed to respond to nearby stratum radiatum stimulation with either an EPSP $(2 / 10)$ or an IPSP (4/10; Fig. 5C3).

These data suggest that the interneurons present following $\mathrm{KA}$ were functional at the time when $\mathrm{CAl}$ was hyperexcitable. As was the case for the hyperexcitable pyramidal cells in lesioned tissue, there also appeared to be a loss of postsynaptic potentials in the interneurons. Loss of either the IPSP $(4 / 10)$ or EPSP $(2 /$ 10 ) occurred in a total of $5 / 10$ interneurons studied at 2-4 weeks. While this is a significant percentage of interneurons recorded, these results were interpreted with caution since the loss of PSPs was not accompanied by a change in $R_{\mathrm{in}}$, which would be expected with a dramatic change in the number of synapses impinging on the interneurons.

\section{Postsynaptic features of inhibition}

GABA receptor complex binding sites

Prior to binding analysis it was first determined that there was no significant shrinkage of $\mathrm{CA} 1$ stratum radiatum that may have contaminated subsequent results. The average widths of the CA1 apical dendritic region determined microscopically were as follows: $2-4$ weeks post-KA, $390 \pm 18 \mu \mathrm{m}, n=3 ; 2-4$ months post-KA, $394 \pm 28 \mu \mathrm{m}, n-3$; unlesioned controls, $398 \pm 34$ $\mu \mathrm{m}, n=3$.

The distribution of FLU binding in normal hippocampus $(A)$ and in hippocampus lesioned 2-4 weeks $(B)$ or 2-4 months $(C)$ earlier is shown in Figure 6 . The boxes outlined indicate the regions that were scanned densitometrically. Densitometric binding analysis demonstrated that specific FLU binding in both stratum radiatum and the dentate molecular layer was saturable in each of the treatment groups examined. Scatchard plots of 

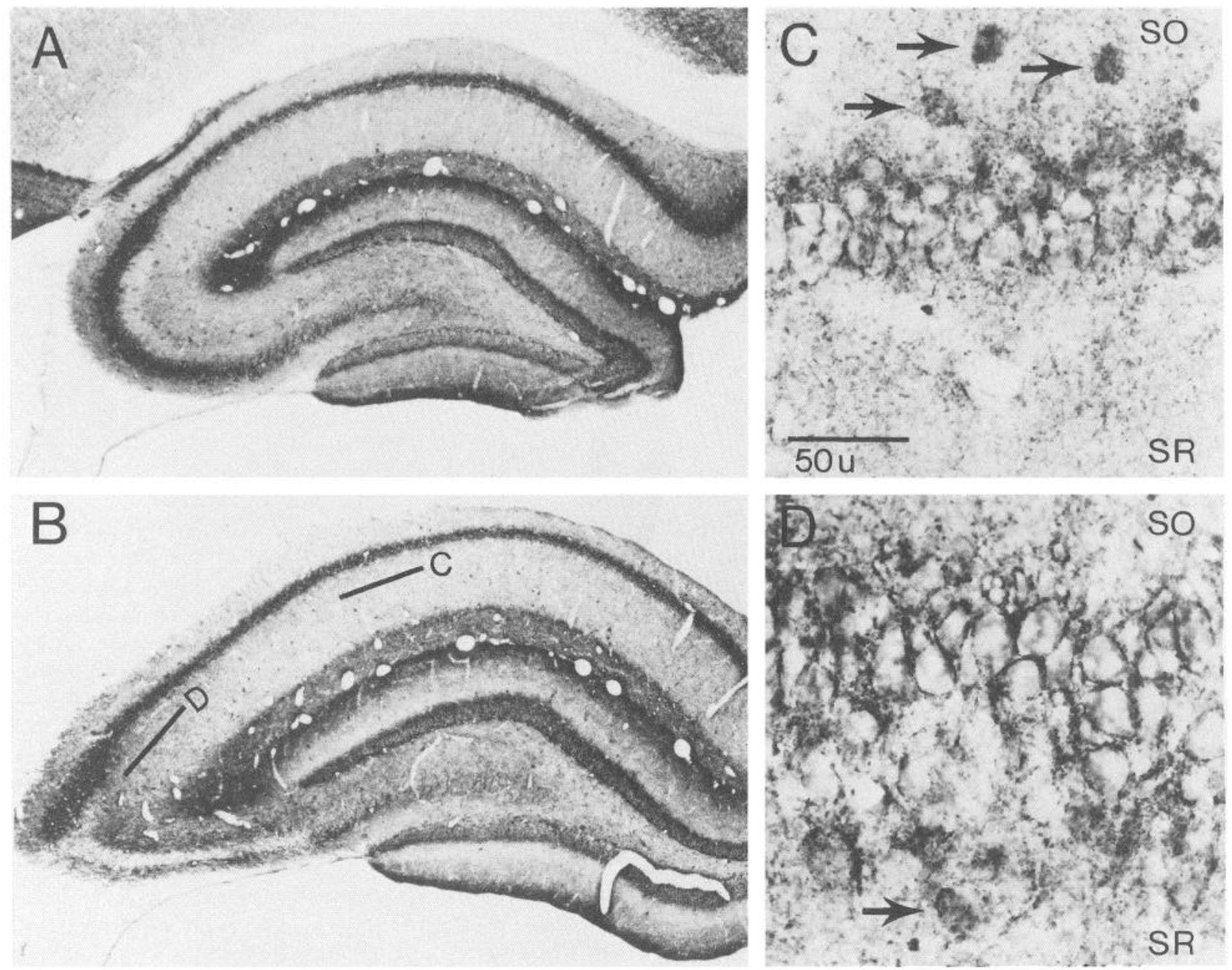

Figure 4. GAD immunoreactivity in normal tissue $(A)$ and tissue lesioned $2-4$ weeks previously $(B-D)$. Low-power micrographs $(\times 2.5)$ demonstrate little qualitative change in either the presence or distribution of GAD-positive somata or terminal fields in control versus hyperexcitable tissue. The location of the micrographs shown in $C$ and $D$ are indicated by the lines in $B$. When CA1 $(C)$ and portions of CA2 $(D)$ are examined at higher magnification $(\times 25)$, both GAD-reactive somata (arrows) and a normal pericellular distribution of GAD-positive terminal puncta are observed in lesioned tissue. so, stratum oriens; $s r$, stratum radiatum.

the binding data were linear in all regions and conditions examined, consistent with binding to a single population of receptors. The saturation experiments were replicated 5 times. Table 2 summarizes the results of the Scatchard analyses for all replicates expressed as a percentage of the coincubated controls.

At 2-4 weeks postlesion, FLU receptor number in CA1 stratum radiatum was modestly but significantly increased; by $2-4$ months, receptor number had declined to near-control levels. There were no significant changes in receptor affinity, nor was FLU binding altered in the dentate gyrus.

We found no differences in tritium quenching within hippocampus due to the lesion condition. The mean optical densities and SEs of 8 readings over CA1 stratum radiatum resulting from the ornithine coating procedure in a typical experiment were as follows: control, $0.2124 \pm 0.009 ; 2-4$ weeks, $0.209 \pm$ 0.01 ; and $2-4$ months, $0.2245 \pm 0.005$.

\section{GABA responses in lesioned tissue}

Pyramidal cells examined for GABA responses were from the $2-4$ weeks postlesion tissue only. Five neurons were examined that discharged aberrant bursts and showed no IPSP in response to stimulation. In each cell, GABA application in the immediate vicinity of the recording electrode produced a hyperpolarization and associated conductance increase (Fig. 7, $A$ and $B$ ). Like the normal, 2-component, IPSP, the early phase of this hyperpolarizing potential was easily reversed with progressively increasing hyperpolarizing current injection (Fig. 7C); the later component decreased in amplitude with increasing current but was not reversed.

Table 2. Summary of flunitrazepam binding data from all replicates in CA1 stratum radiatum and the dentate gyrus stratum moleculare

\begin{tabular}{llllrr} 
& \multicolumn{2}{l}{$\begin{array}{l}\text { CAl stratum } \\
\text { radiatum }\end{array}$} & & \multicolumn{2}{l}{$\begin{array}{l}\text { Dentate stratum } \\
\text { moleculare }\end{array}$} \\
\cline { 2 - 3 } \cline { 5 - 6 } Group & $B_{\max }$ & $K_{d}$ & & $B_{\max }$ & \multicolumn{1}{c}{$K_{d}$} \\
\hline 2-4 weeks $(n=5)$ & $115 \pm 2^{a}$ & $110 \pm 10$ & & $101 \pm 5$ & $90 \pm 6$ \\
2-4 months $(n=5)$ & $106 \pm 3$ & $103 \pm 6$ & & $96 \pm 4$ & $100 \pm 7$
\end{tabular}

Data are expressed as a percentage of control values.

${ }^{\circ} p=0.006$, normal distribution. 

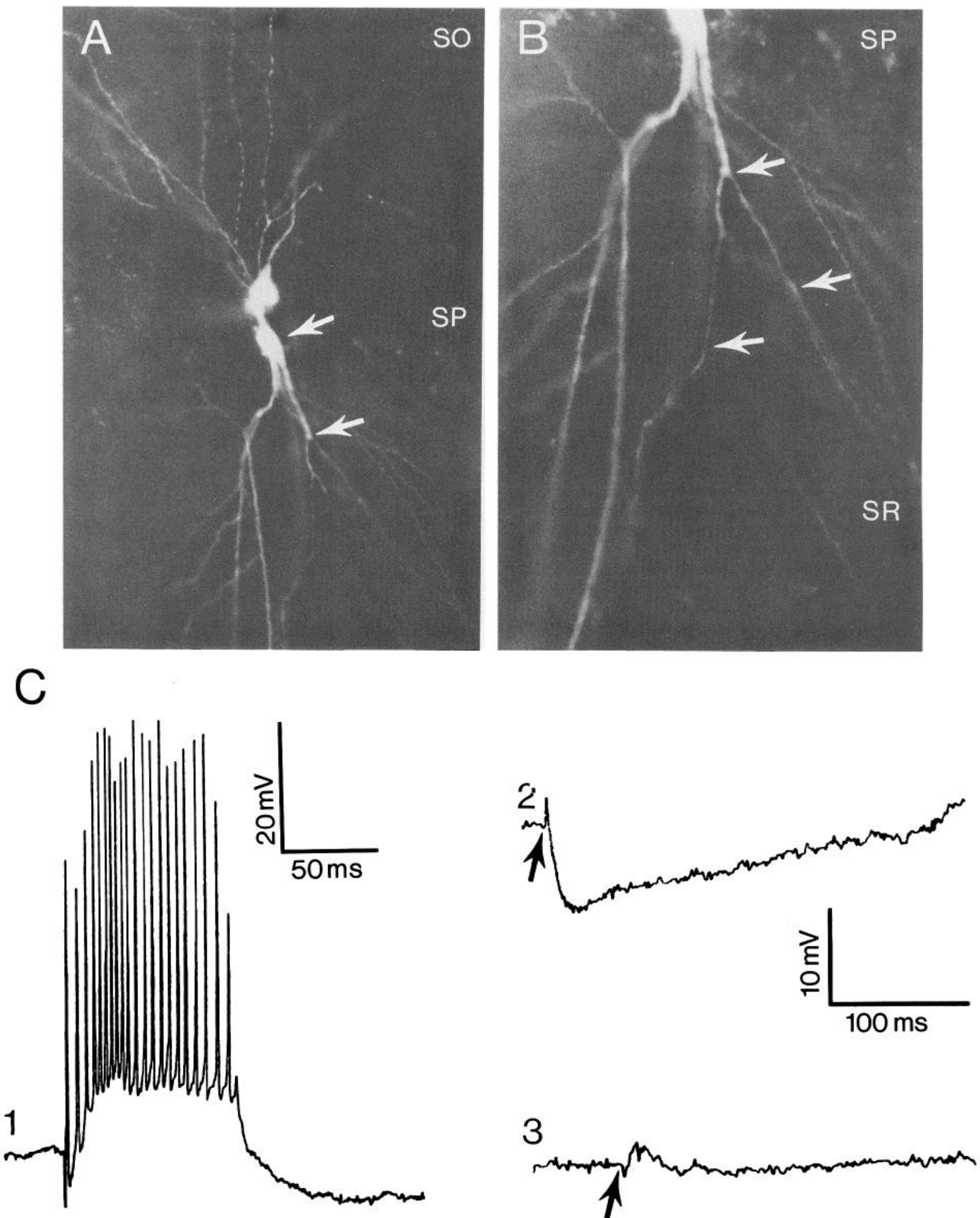

Figure 5. A dye-filled nonpyramidal cell in hyperexcitable CA1 $2-4$ weeks postlesion. The presumed interneuron shown appears dye-coupled to a pyramidal cell $(A)$. The interneuron apical dendrite bifurcates once, and 2 branches descend into stratum radiatum $(B$, arrows). This cell responded to depolarizing current injection with a typical spike train $(C I)$. Orthodromic stimulation (arrows) elicited an IPSP (C2) when the stimulating electrode was close to the recording electrode and an EPSP when stimulation was moved further out into stratum radiatum (C3). so, stratum oriens; $s p$, stratum pyramidale; $s r$, stratum radiatum. 


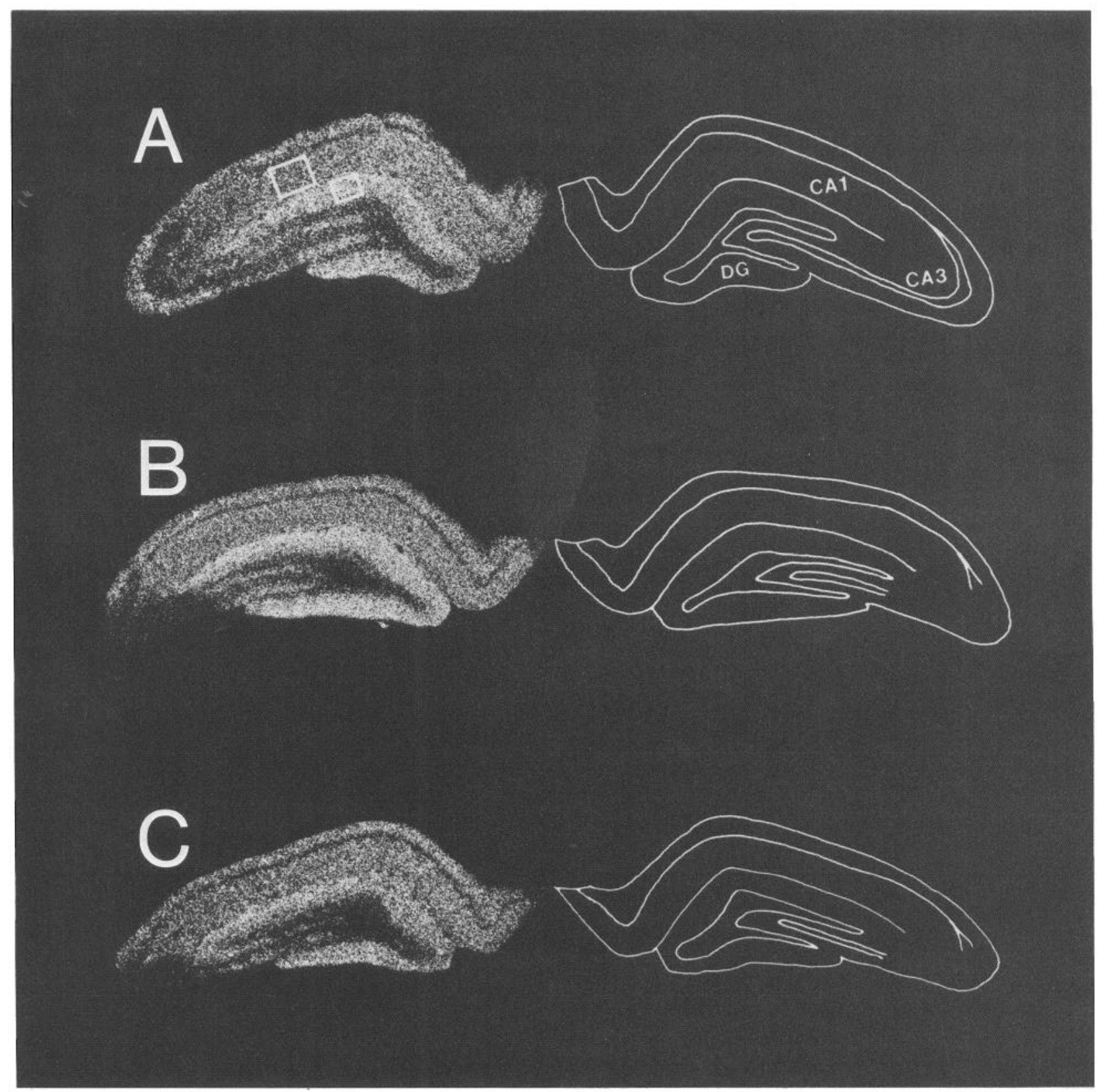

Figure 6. In vitro autoradiograms of tritiated flunitrazepam binding in normal $(A), 2-4$ weeks postlesion $(B)$, and $2-4$ months postlesion hippocampi (C). A representative autoradiogram appears on the left, and corresponding line drawings showing the location of neuronal subfields and the extent of the lesion appear on the right. The boxes in $A$ denote the approximate regions scanned for quantitative analysis.

\section{Discussion}

This work extends our previous results (Franck and Schwartzkroin, 1985), and the results of others (Ashwood et al., 1986), demonstrating that loss of CA3 induces an aberrant hyperexcitability in CA1 that is associated with a loss of functional inhibition. We show that (1) when inhibition is absent, 2-4 weeks postlesion, there is no decline in the number of presumed GABAergic neurons or in the appearance of their pericellular terminal distribution in $\mathrm{CA} 1 ;(2)$ these interneurons are viable but, like pyramidal cells, may have a reduced occurrence of IPSPs; (3) when CA1 is hyperexcitable, there is an increase in number of the $\mathrm{GABA}_{\mathrm{A}}-\mathrm{BZ}$ receptor complex; (4) at more chronic postlesion latencies, hyperexcitability in CA1 population and single-cell responses is attenuated; this attenuation is coincident with a recovery of the early, $\mathrm{GABA}_{\mathrm{A}}$ mediated, IPSP; and (5) the late IPSP fails to recover.

\section{Physiology of lesioned hippocampi}

The population response observed at 2-4 weeks postlesion, reflecting synchronous uninhibited bursts in a large population of neurons, is dramatically abnormal. The observation that a component of the IPSP reappears at longer postlesion latencies (when synaptic bursting ceases to be predominant) reflects a partial recovery in this tissue. This interpretation is consistent with findings that spontaneous electrographic and behavioral seizures 

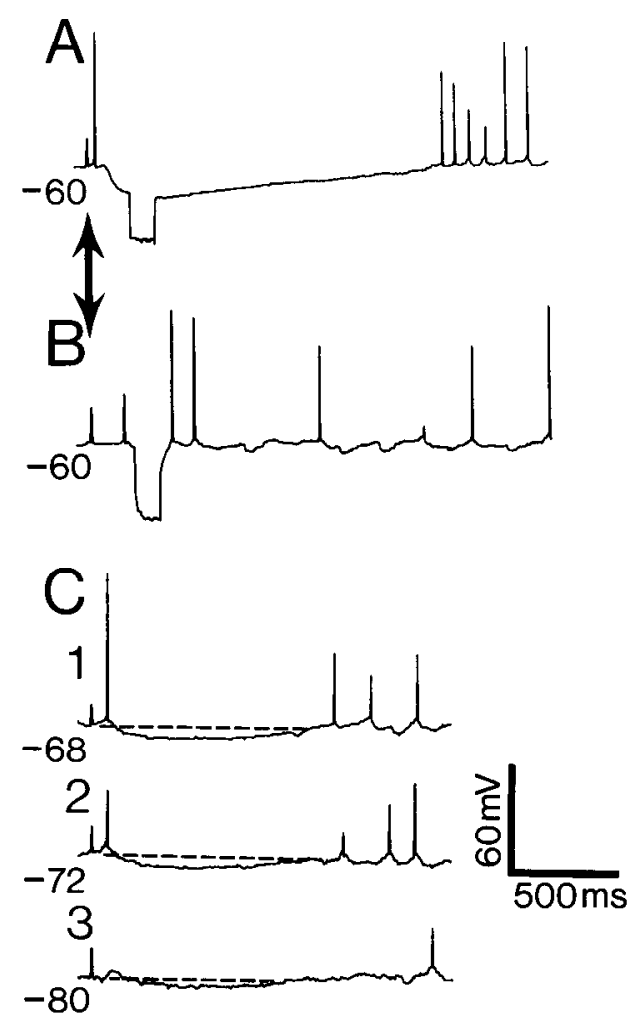

Figure 7. Response of a hyperexcitable pyramidal cell from tissue lesioned 2-4 weeks previously to local pressure ejection of GABA. GABA produced a prolonged hyperpolarization $(A)$ and a conductance increase, as demonstrated by the injection of $0.5 \mathrm{nA}$ of hyperpolarizing current with $(A)$ or without $(B)$ GABA application. The effect of constant hyperpolarizing current on the GABA response in a cell from hyperexcitable tissue $(C)$ is like that of current on the synaptically produced IPSP in normal tissue. As increasing amounts of current are applied ( $\mathrm{Cl}-3)$, the early IPSP is reversed, but the later component, while decreased, fails to reverse completely.

decrease at long latencies following KA lesions (Cavalheiro et al., 1982) and with the demonstration of recovery of function following KA disruption of nonseizure phenomenon (Handelmann and Olton, 1981). It should be emphasized, however, that our measures suggest that recovery is not complete. Subtle multiple population responses could still be elicited in slices from 2-4 month tissue. In addition, while IPSPs do reappear at longer intervals postlesion, the total duration of these hyperpolarizations is much less than in normal tissue. The IPSP peak in such cells occurred at a short latency from the stimulus, consistent with measurements of the early IPSP peak (Knowles et al., 1984; Kehl and McLennan, 1985). This peak latency did not differ between treatment groups, suggesting that the significantly abbreviated hyperpolarization observed at long intervals postlesion reflects a chronic loss or reduction in the late IPSP (Alger and Nicoll, 1982; Knowles et al., 1984). These observations contrast with those of Ashwood et al. (1986), who studied tissue 1 weck postlesion and reported that the late IPSP persists in CA1 neurons from KA-treated slices and that loss of the early IPSP was most apparent when orthodromic stimulation was used. In our tissue studied at a similar time point ( 2 weeks), we found that both the early and late IPSP are absent in most cells following either ortho- or antidromic stimulation. The most likely explanation for this discrepancy lies in the nature of the lesion. The bilateral lesion in our animals produces more extensive denervation than the unilateral cell damage examined hy Ashwood et al. (1986); the latter lesion leaves commissural connections intact, and different components of inhibitory and excitatory circuitry may be altered as a result.

While the primary focus of this work was to examine inhibition in hyperexcitable tissue, the experiments performed following CA1 isolation in aberrant slices suggest that recurrent excitation also plays a role in synchronizing excitable cells. Such a recurrent system has not been demonstrated in CA1 (Knowles and Schwartzkroin, 1981). However, a small number of pyramidal cell-to-pyramidal cell excitatory connections may be present in $\mathrm{CA} 1$ and become more efficient when not antagonized by normal inhibition.

\section{Morphologic versus functional inhibition}

The present data indicate that CA1 hyperexcitability is not associated with a major loss of GABAergic neuronal somata or their terminals surrounding pyramidal cell bodies. Our recordings from physiologically and morphologically identified nonpyramidal neurons also indicates that these cells were grossly functional. Our failure to find interneuron loss in hyperexcitable tissue is consistent with the preliminary results of other investigators (Davenport and Babb, 1985) but contrasts with the work of Ben-Ari and his colleagues, who have studied hippocampi lesioned by systemic KA (Nitecka et al., 1984; BenAri, 1985). These investigators report extensive interneuron loss but also demonstrate that this route of KA administration produces more prominent loss of CA1 pyramidal cells than does intraventricular toxin injection. We have also found extensive CA1 pyramidal cell and interneuron loss following systemic KA in developing animals (in the absence of CA3 damage) (Franck and Schwartzkroin, 1984) and have suggested, as have others (Lassman et al., 1984), that the 2 routes of administration produce differing patterns of damage by differing mechanisms. The resulting hyperexcitability in the 2 preparations may involve different substrates, with interneuron loss a major factor in only one.

At 2-4 weeks postlesion, when most CA1 pyramidal cells have neither early nor late IPSPs, the affinity and number of modulatory $\mathrm{BZ}$ binding sites on the $\mathrm{GABA}_{\mathrm{A}}$ complex did not decline; in fact, there was a modest, but significant, increase in total number of binding sites on CA1 neurons, a change that returned to normal at a time when the early, $\mathrm{GABA}_{\mathrm{A}}$-mediated, IPSP recovered. These data suggest that the alterations that occur in hyperexcitable tissue at the early postlesion latency, at least in these measures of the GABA-complex function, are compensatory in nature. It would be of interest to determine if markers for the late IPSP-related $\mathrm{GABA}_{\mathrm{B}}$ binding site are altered in a more chronic fashion since this late inhibitory potential fails to recover.

The failure of inhibition at 2-4 weeks in KA-lesioned hippocampi, in the presence of apparently normal (or supranormal) pre- and postsynaptic markers for inhibitory function, suggests a functional "uncoupling" between the production and/or release of GABA at the presynaptic terminal and its recognition or accessibility to the postsynaptic site. This possibility is consistent with the demonstration (see also Ashwood and Wheal, 1986) that hyperexcitable CA1 pyramidal cells respond "normally" to exogenously applied GABA. Several features of inhibitory function remain to be tested. For example, GABA synthesis may be compromised, although this possibility seems unlikely since even more extensive hippocampal lesions do not totally disrupt GABA synthesis (Schwarcz et al., 1978). Alter- 


\section{NORMAL}

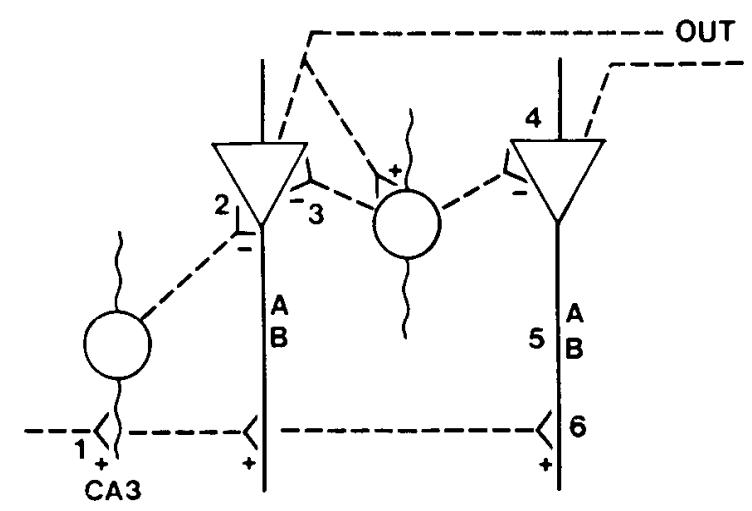

2-4 WEEKS

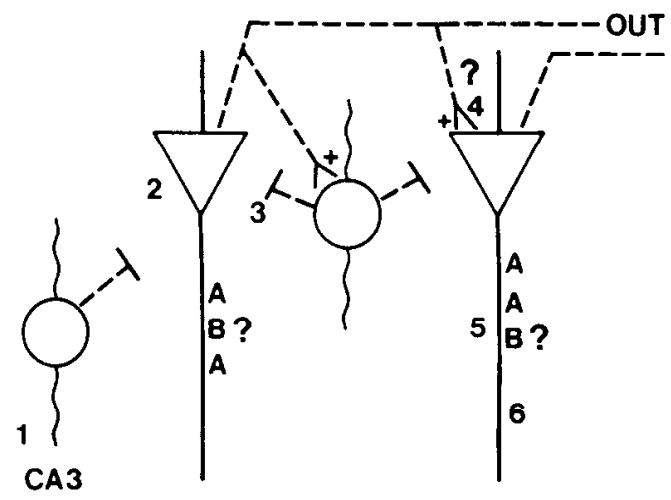

2-4 MONTHS

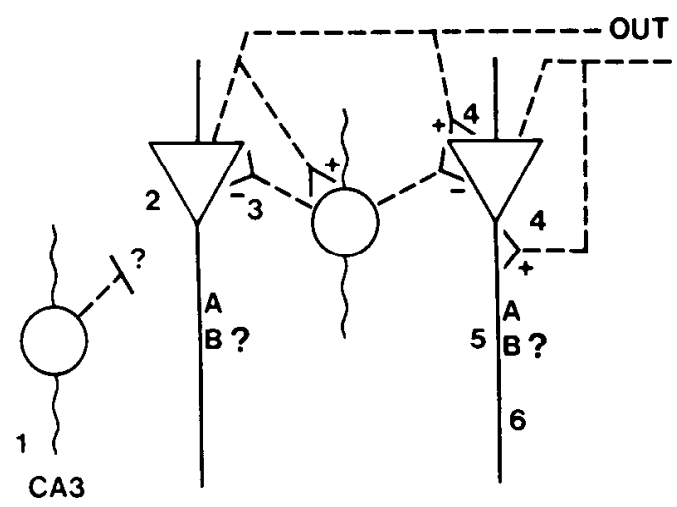

Figure 8. Hypothesized lesion consequences. Features of normal hippocampi include ( 1 ) feedforward activation of interneurons; (2) late IPSPs in pyramidal cells mediated by these interncurons; (3) recurrent, early IPSPs; (4) recurrent excitation (absent in normal tissue); (5) GA$\mathrm{BA}_{\mathrm{A}}$ and $\mathrm{GABA} \mathrm{B}_{\mathrm{B}}$ receptors; and (6) CA3 input to $\mathrm{CA} 1$.

Features of 2-4 week postlesion hippocampi may include $(I)$ loss of feedforward interneuron activation from CA3; (2) loss of late IPSPs as a result of $I$; (3) loss of early IPSPs due to some disruption at the interneuron-pyramidal cell synapse; (4) beginning of recurrent excitation; (5) compensatory increase in $\mathrm{GABA}_{\mathrm{A}}$ receptors due to loss of early IPSPs (the effects on the GABA ${ }_{B}$ site are unknown); and (6) deafferentation of CAl dendrites.

Features of 2-4 month postlesion hippocampi may include (I) per- natively, GABA release may be reduced, an attractive hypothesis in light of the suggestion that acute effects of KA on inhibition in vitro is due to an alteration of presynaptic transmitter release (Fisher and Alger, 1984).

A different, but related, hypothesis for the loss of functional inhibition is that GABA may not have access to postsynaptic sites because there is a morphologic "disconnection" between local excitatory and inhibitory elements. Several alterations may occur in lesioned hippocampi to produce such a disconnection. First, the CA3 lesions destroy roughly $85 \%$ of the excitatory synapses onto CA1 apical dendrites (Nadler et al., 1980b). Such a denervation also reduces excitatory synaptic drive onto the dendrites of several types of hippocampal interneurons that radiate extensively in stratum radiatum and mediate, in part, feedforward inhibition (Schwartzkroin and Kunkel, 1985; Lacaille and Schwartzkroin, 1988). Feedforward inhibition in hippocampus may be an important mechanism of the late IPSP (Alger and Nicoll, 1982). Thus, deafferentation of some interneurons may explain the chronic loss of this potential. Second, feedback inhibition (e.g., as seen with alveus stimulation) also is compromised. Although we observed a dense GAD-positive terminal plexus in stratum pyramidale of CAl in lesioned tissue, Hoff et al. (1981) have shown that selective denervation of one afferent to a group of neurons can result in a transient "shedding," without degeneration, of other, unrelated afferents. Thus, massive loss of excitatory contacts on CA1 apical dendrites may induce a shedding, or detachment, of unlesioned terminals, including GAD-positive somatic boutons. Recovery of the early IPSP at later postlesion intervals may then involve terminal "reattachment" at these synapses. Alternatively, the disruption may be at the level of recurrent pyramidal cell excitation of interneurons. Finally, it is possible that the lesion disrupts an inhibitory pathway from CA3 to CA1.

Figure 8 schematically summarizes the hypothetical sequence of alterations in lesioned tissue suggested by the present data. There are several types of hippocampal inhibitory interneurons categorized, in part, on the basis of location and the way in which they interact with pyramidal cells. All types may be excited in a feedforward fashion. Some types, by virtue of their location, distant to the pyramidal cell layer (e.g., in stratum lacunosum; Lacaille and Schwartzkroin, 1988), may depend more on feedforward excitation than do interneurons near the pyramidal cells (e.g., basket cells or oriens-alveus interneurons; Schwartzkroin and Kunkel, 1985). These proximal interneurons, again, by virtue of location, may more preferentially mediate recurrent inhibition. In Figure 8 we have illustrated these 2 gencral types of interneurons. In the present study, we recorded only from interneurons within, or near, stratum pyramidale. Based on the above considerations, however, it may be that the inhibition mediated by the more distal interneuron types is the more severely and permanently compromised.

sistent deafferentation of some interneurons; (2) continued failure of late IPSP, due either to a loss of interneuron activation or to persistent changes at their contacts with pyramidal cells; (3) return of the early IPSP; (4) well-established recurrent excitation; (5) $\mathrm{GABA}_{\mathrm{A}}$ receptor levels return to normal (fate of $\mathrm{GABA}_{B}$ receptors currently unknown); and (6) continued absence of CA3 input to CA1. The placement of different synapses and of GABA binding sites is for graphic purposes only and does not imply their actual location on CAI cells. 


\section{Hyperexcitability versus "recovery"}

The present work stresses features of inhibition during periods of hyperexcitability following a lesion that may be relevant to human temporal focal seizures. However, the functional consequences of this lesion change with time. The earliest time we examined lesioned tissue was 2 weeks after surgery. Other investigators have studicd the samc lesion at 1 weck (Ashwood and Wheal, 1986; Ashwood et al., 1986). At 1-2 weeks postlesion, CAl denervation is maximal; by 2 months, reinnervation, perhaps by recurrent $\mathrm{CA} 1$ collaterals, is almost complete (Nadler et al., 1980a). The chronic morphologic alterations, to the extent that they reflect the functional capabilities of the tissue after "compensatory" neuroplastic rearrangement, are certainly of as great an interest as those produced at short postlesion latencies, which may primarily be responses to trauma.

We have indicated that CA1 shows partial "recovery" at long postlesion intervals but that some abnormal features persist at 2-4 months postlesion. These abnormalities include small multiple population spikes elicited by radiatum stimulation and failure of late IPSP recovery. A recurrent excitatory collateral system may develop between CA1 pyramidal cells. In our previous work, we also demonstrated that pyramidal $R_{\text {in }}$ remained high relative to controls. These features reflect a continued dysfunction in lesioned tissue, perhaps mediated by mechanisms different from those operating at acute postlesion latencies. It is important to emphasize, however, that spontaneous bursts and afterdischarge activity were not observed in single cells studied several months postlesion. This result suggests that a partially recovered IPSP is quite effective in limiting cell firing, even in this compromised tissue.

\section{Lesion model of epilepsy}

The chronic KA model is becoming increasingly discussed as a relevant tool in the study of complex partial seizures (Ben-Ari, 1985; Ashwood et al., 1986). The lesions produced in this model are similar to those seen in clinical material; the lesions do produce behavioral and electrographic seizures; and a primary pathology appears to involve remaining neurons in hippocampus. However, several questions remain regarding the model. First, do similar lesions, produced by a treatment that does not itseif cause seizures, produce a similar postlesion symptomatology or do the long-lasting seizures produced by KA result in a kindling-like phenomenon? Second, how does this model "fit" with data from other models of partial seizures and from studies on human material? Data from the alumina cream model suggest that morphologic changes at the presumcd focus involvc a loss of the substrates for GABAergic function; both GAD-positive interneurons and their terminals are lost (Ribak, 1986), and there is a decrease in receptors for GABAergic ligands (Bakay and Harris, 1981). These observations are not consistent with the results of our study of the KA model. In contrast, studies of human tissue (patients diagnosed as having partial seizures of temporal lobe origin, i.e., patients most likely to have hippocampal cell loss) suggest that a simple loss of functional inhibition and its morphologic substrate, interneurons and receptors, may not always occur in temporal lobe foci. In vitro recording from resected human temporal lobe indicates that inhibitory function, while reduced, persists in this tissue (Schwartzkroin, 1986) and may even synchronize cell discharge (Schwartzkroin and Haglund, 1986). In vivo presurgical depth recording confirms the presence of inhibition and has further shown that interneurons are present in necrotic epileptic hippocampi (Babb and Brown, 1986). Thus, complex partial seizures in general, and those of temporal lobe origin in particular, may not result from a simple focal loss of inhibitory function but may rely more on increased excitation.

The KA lesion model remains intriguing for the apparent dissociation of functional inhibition (dramatically reduced, at least temporarily) and its morphologic substrates (maintained). At long recovery intervals, inhibition and hyperexcitability (although not as dramatic as at acute postlesion latencies) seem to coexist, much as in human temporal foci. Experimental models of hippocampal cell death thus appear to be of interest for providing insight into the mechanisms of idiopathic and posttraumatic temporal lobe seizures.

\section{References}

Alger, B. E. (1984) Characteristics of a slow hyperpolarizing synaptic potential in rat hippocampal pyramidal cells in vitro. J. Neurophys. 52: 892-910.

Alger, B. E., and R. A. Nicoll (1982) Feedforward dendritic inhibition in rat hippocampal pyramidal cells studied in vitro. J. Physiol. (Lond.) 328: $105-122$.

Ashwood, T. J., and H. V. Wheal (1986) Loss of inhibition in the CAl region of the kainic acid lesioned hippocampus is not associated with changes in postsynaptic responses to GABA. Brain Res. 367 : 390-394.

Ashwood, T. J., B. Lancaster, and H. V. Wheal (1986) Intracellular electrophysiology of CAI pyramidal neurones in slices of the kainic acid lesioned hippocampus of the rat. Exp. Brain Res. 62: 189-198.

Babb, T. L., and W. J. Brown (1986) Neuronal, dendritic, and vascular profiles of human temporal lobe epilepsy correlated with cellular physiology in vivo. In Advances in Neurology, Vol. 44, Basic Mechanisms of the Epilepsies, A. Delgado-Escueta, A. Ward, D. Woodbury, and R. Porter, eds., pp. 949-966, Raven, New York.

Bakay, R. A. E., and A. B. Harris (1981) Neurotransmitter, receptor and biochemical changes in monkey cortical epileptic foci. Brain Res. 206: 387-404.

Baskin, D. G., D. Davidson, E. S. Corp, T. Lewellen, and M. Graham (1986) An inexpensive microcomputer digital imaging system for densitometry: Quantitative autoradiography of insulin receptors with 125-I and LKB Ultrofilm. J. Neurosci. Methods 16: 119-129.

Ben-Ari, Y. (1985) Limbic seizure and brain damage produced by kainic acid: Mechanisms and relevance to human temporal lobe epilepsy. Neuroscience 14: 375-403.

Cavalheiro, E., D. Riche, and G. Le Gal La Salle (1982) Long-term effects of intrahippocampal kainic acid injections in rats; a method for inducing spontaneous recurrent seizures. Electroencephalogr. Clin. Neurophysiol. 53: 581-589.

Cotman, C. W., A. C. Foster, and T. H. Lanthorn (1981) An overview of glutamate as a neurotransmitter. Adv. Biochem. Pharmacol. 27. $1-27$.

Davenport, C. J., and T. L. Babb (1985) $\mathrm{GAD}^{+}$neurons for GABA mediated inhibition in kainate-hippocampal epilepsy. Soc. Neurosci. Abstr. 11: 284.

Enna, S. J., and E. W. Karbon (1986) GABA receptors: An overview. In Benzodiazepine/GABA Receptors and Chloride Channels, R. W. Olsen and J. C. Venter, eds., Liss, New York.

Fisher, R. S., and B. E. Alger (1984) Electrophysiological mechanisms of kainic acid induced epileptiform activity in the rat hippocampal slice. J. Neurosci. 4: 1312-1323.

Foster, A. C., E. E. Mena, D. T. Monaghan, and C. W. Cotman (1981) Synaptic localisation of kainic acid binding sites. Nature 289: 73-75.

Franck, J. E. (1984) Dynamic alterations in hippocampal morphology following intraventricular kainic acid. Acta Neuropathol. 62: 242253.

Franck, J. E., and P. A. Schwartzkroin (1984) Immature rabbit hippocampus is damaged by systemic but not intraventricular kainic acid. Dev. Brain Res. 13: 219-227.

Franck, J. E., and P. A. Schwartzkroin (1985) Do kainate-lesioned hippocampi become epileptogenic? Brain Res. 329: 309-313.

Geary, W. A., A. W. Toga, and G. F. Wooten (1985) Quantitative 
film autoradiography for tritium: Methodological considerations. Brain Res. 337: 99-108.

Handlemann, G. E., and D. S. Olton (1981) Recovery of function after neurotoxic damage to the hippocampal CA3 region: Importance of postoperative recovery interval and task experience. Behav. Neural Biol. 33: 453-464.

I Herkenham, M., and L. Sokoloff (1984) Quantitative receptor autoradiography: Tissue defatting eliminates differential self-absorption of tritium radiation in gray and white matter of brain. Brain Res. 321: 363-368.

Hoff, S. F., S. W. Scheff, A. Y. Kwan, and C. W. Cotman (1981) A new type of lesion-induced synaptogenesis: I. Synaptic turnover in non-denervated zones of the dentate gyrus in young adult rats. Brain Res. 222: 1-13.

Kehl, S. J., and H. McLennan (1985) An electrophysiological characterization of inhibitions and postsynaptic potentials in rat hippocampal CA3 neurones in vitro. Exp. Brain Res. 60: 299-308.

Knowles, W. D., and P. A. Schwartzkroin (1981) Local circuit synaptic interactions in hippocampal brain slices. J. Neurosci. 1: 318-322.

Knowles, W. D., J. H. Schneiderman, H. V. Wheal, C. E. Stafstrom, and P.A. Schwartzkroin (1984) IIyperpolarizing potentials in guinea pig hippocampal CA3 neurons. Cell. Mol. Biol. 4: 207-230.

Kunkel, D. D., A. E. Hendrickson, J.-Y. Wu, and P. A. Schwartzkroin (1986) Glutamic acid decarboxylase immunocytochemistry of developing rabbit hippocampus. J. Neurosci. 6: 541-552.

Lacaille, J.-C., and P. A. Schwartzkroin (1988) Stratum lacunosummoleculare interneurons of hippocampal CAl region. II. Intrasomatic and intradendritic recordings of local circuit synaptic interactions. J. Neurosci. 8: 1411-1424.

Lassmann, H., U. Petsche, K. Kitz, H. Baran, G. Sperk, F. Seitelberger, and O. Hornykiewicz (1984) The role of brain edema in epileptic brain damage induced by systemic kainic acid injection. Neuroscience 13: 691-704.

Nadler, J. V., B. W. Perry, and C. W. Cotman (1980a) Selective reinnervation of hippocampal area CA1 and the fascia dentata after destruction of CA3-CA4 afferents with kainic acid. Brain Res. 182. 1-9.

Nadler, J. V., B. W. Perry, C. Gentry, and C. W. Cotman (1980b) Loss and reacquisition of hippocampal synapses after selective destruction of CA3-CA4 afferents with kainic acid. Brain Res. 191: 387-403.

Nitecka, L., E. Tremblay, G. Charton, J. P. Bouillot, M. L. Berger, and Y. Ben-Ari (1984) Maturation of kainic acid seizure brain damage syndrome in the rat II. Histopathologic sequelae. Neuroscience 13: 1073-1094.

Oertel, W. H., D. E. Schmechel, E. Mugnani, and I. J. Kopin (1981) Immunocytochemical localization of glutamate decarboxylase in rat cerebellum with a new antiserum. Neuroscience 6: 2715-2735.

Olney, J. W. (1978) Neurotoxicity of excitatory amino acids. In Kainic Acid as a Tool in Neurobiology, E. G. McGeer, J. W. Olney, and P. L. McGeer, eds., pp. 95-121, Raven, New York.

Pellegrino, L. J., and A. J. Cushman (1967) A Stereotaxic Atlas of the Rat Brain, Appleton-Century-Crofts, New York.

Ribak, C. E. (1986) Contemporary methods in neurocytology and their application to the study of epilepsy. In Advances in Neurology, Vol. 44, Basic Mechanisms of the Epilepsies, A. Delgado-Escueta, A. Ward, D. Woodbury, and R. Porter, eds., Raven, New York.

Schwarcz, R., R. Zaczek, and J. Coyle (1978) Microinjection of kainic acid into the rat hippocampus. Eur. J. Pharmacol. 50: 209-220.

Schwartzkroin, P. A. (1986) Hippocampal slices in experimental and human epilepsy. In Advances in Neurology, Vol. 44, Basic Mechanisms of the Epilepsies, A. Delgado-Escueta, A. Ward, D. Woodbury, and R. Porter, eds., Raven, New York.

Schwartzkroin, P. A., and M. Haglund (1986) Spontaneous rhythmic synchronous activity in epileptic human and normal monkey temporal lobe. Epilepsia 27: 523-533.

Schwartzkroin, P. A., and D. D. Kunkel (1985) Morphology of identified interneurons in the CA1 regions of guinea pig hippocampus. J. Comp. Neurol. 232: 205-218.

Schwartzkroin, P. A., and L. H. Mathers (1978) Physiological and morphological identification of a nonpyramidal hippocampal cell type. Brain Res. 157: 1-10.

Sternberger, L. A. (1979) Immunocytochemistry, Wiley, New York.

Tanaka, T., M. Kaijima, Y. Yonemasu, and C. Cepeda (1985) Spontaneous secondarily generalized seizures induced by a single microinjection of kainic acid into unilateral amygdala in cats. Electroencephalogr. Clin. Neurophysiol. 61: 422-429.

Tauck, D. I., and J. V. Nadler (1985) Evidence of functional mossy fiber sprouting in hippocampal formation of kainic acid-treated rats. J. Neurosci. 5: 1016-1022.

Unnerstall, J. R., D. L. Niehoff, M. J. Kuhar, and J. M. Palacios (1982) Quantitative receptor autoradiography using 3H-Ultrofilm: Application to multiple benzodiazepine receptors. J. Neurosci. Methods 6: $59-73$. 